\title{
ZONE PROXIMAL DEVELOPMENT GIVES A NEW MEANING TO THE STUDENTS' INTELLIGENCE IN STATISTICAL METHOD LESSON
}

\author{
Georgina Maria Tinungki \\ Hasanuddin University, Jl. Perintis Kemerdekaan KM.10, Makassar 90245, Indonesia \\ Email: georgina@unhas.ac.id
}

\begin{abstract}
Abstrak
Pengembangan Zone of Proximal Development (ZPD) seorang pelajar membutuhkan bimbingan, bantuan dari orang dewasa atau teman sebaya dengan keahlian yang lebih tinggi untuk mencapai tingkat perkembangan yang lebih tinggi. Tingkat pengetahuan atau pengetahuan bertahap disebut oleh Vygotsky sebagai Skafolding. Skafolding berarti memberi bantuan kepada peserta didik selama tahap awal pembelajaran, kemudian mengurangi jumlah bantuan dan memberi kesempatan kepada mereka untuk segera mengambil tanggung jawab yang lebih besar, setelah mampu melakukan tugas sendiri. Salah satu dalam program pelajaran statistika adalah Metode Statistik, yang membutuhkan pemikiran tingkat tinggi karena siswa diharapkan dapat menganalisis inferensi statistik. Dalam hal ini, siswa memerlukan bantuan selama proses pembelajaran agar dapat memahami konsep materi Metode Statistik secara optimal. Bantuan bisa dalam bentuk bimbingan, dorongan, uraian masalah ke dalam bentuk lain, yang memungkinkan siswa untuk mandiri. Dengan mengimplementasikan proses ZPD dalam bentuk tahap skafolding, siswa dapat memahami konsep materi Metode Statistik secara optimal.
\end{abstract}

Kata Kunci: Skafolding, Metode statistika, Zone of Proximal Development (ZPD).

\begin{abstract}
Development of Zone of Proximal Development (ZPD) a learner needs guidance, help from adults or peers with a higher skill set in order of achieve a higher level of development. The level of knowledge or gradual knowledge is called by Vygotsky as scaffolding. Scaffolding means giving learners helps during the early stages of learning, then reducing the quantity of help and giving the learner opportunity to immediately take on the greater responsibility, after being able to do tasks on their own. One in the statistics Lesson program is Statistical Method, which requires high-level thinking since the students are hoped to be able to analyze statistics inference. In this case, students need help during the learning process in order to understand the concept of Statistical Method material optimally. The help could be in the form of guidance, encouragement, outlining problems into other forms that enable students to be independent. By implementing the ZPD process in the form of scaffolding stage, students are able to understand concepts of Statistical Method material optimally.
\end{abstract}

Keywords: Scaffolding, Statistical Method, Zone of Proximal Development (ZPD).

\section{INTRODUCTION}

Zone of Proximal Development (ZPD) can be categorized as a kind of buffer zone in which the learners can reach a higher level of development (Atebe, 2011). In this 
area, the functions or abilities, which are immature or still in the process of being mature, are able to be in the mature stage through interaction and guidance or collaboration with more competent peers (Borchelt, 2007). Regarding ZPD, learners should be provided with a new situation, in this case, a higher-level situation. Furthermore, the provided information should be challenging. Thus, the learner gets challenges facing difficulties. Helps given to the learner is called as scaffolding by Vygotsky (Angeli, et al., 2014).

The learners are expected to always try improving their ability to understand the concept of a learning topic. Learners will always think systematically that will improve their cognitive and skill. Even though the learners are going to learn several concepts through daily experience at the end, Vygotsky believed that the learning will be more developed when students interacting with others. Learners will never be able to develop formal operational thinking without the help of others. This condition is related to understanding the subject of Statistical Method material.

\section{Zone Proximal Development (ZPD)}

Learning through instruction and intermediary is the characteristic of human intelligence (Atebe, 2011). Through the help of an adult, children are able to do and understand many things compare to children who learn by themselves. The concept is called by Vygotsky as Zone of Proximal Development (ZPD). ZPD gives new meaning to the 'intelligence'. Intelligence is not measured by seeing what a child can do with the proper help. Learning to do something and to think is supported by interacting with adults.

Vygotsky proposed three categories of learner achievement in students' attempt to solve problems, namely: learner achieves success well, learner achieves success with help, and learner fails to succeed. Teacher encouragement to the student is truly needed to make an optimal achievement in higher levels of education (Camiciottoli \& FortanetGomez, 2015).

In ZPD, a learner needs guidance, help from adults or peers that are more competent in order to achieve a higher level of development. The following are the stages of a learner's development level in the ZPD process. 


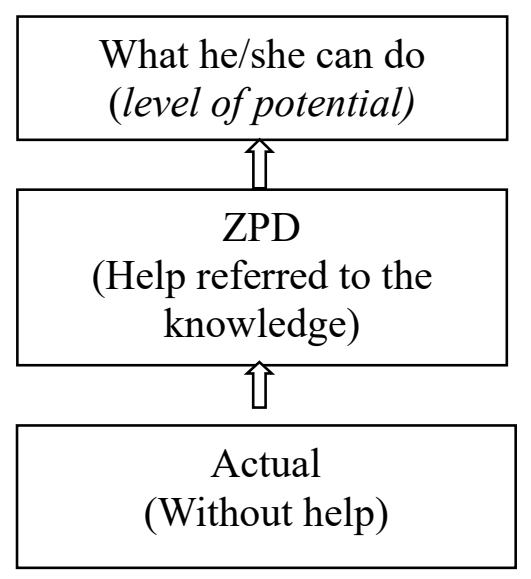

Figure 1. Level of Development (Anthony \& Walshaw, 2009)

Figure 1 stated that, in fact, each learner has different ZPD, in this case, ZPD always empowers actual. Help provided to learners should be in accordance with their respective ZPD and should be assessed in accordance with authentic assessment (Anthony \& Walshaw, 2009). The level of knowledge or the gradual knowledge by Vygotsky is called scaffolding. Scaffolding means giving an individual helps during the early stages of learning and then reducing the help and giving the learner the opportunity to take greater responsibility immediately after being able to do tasks on their own. The help for the learner could be in the form of guidance, warning, encouragement, outlining problems into other forms that enable students to be independent (Padayachee, et al., 2011).

Vygotsky proposed three categories of students' achievement in their attempt to solve problems, i.e. Learner achieves success, Learner achieves success with help, and Learner fails to succeed. Scaffolding means teacher's effort to guide the learners gaining success. Encouragement of teachers is needed for the optimal achievement of learners in higher level. Scaffolding is help given to the learner, after becoming independent, the help will be reduced gradually so that the learner feels that they are already able to be independent and will keep growing based on their ability. Many of Vygotsky's ideas are helpful in building a frame of mind. To make decisions on what teachers can do to support learning, we can use the idea that adults act as intermediaries. "Then ... what else can learners learn?". This can have an impact on how to prepare lessons or how teachers should speak with the learner at all times (Ndlovu, 2011). ZPD can be a guide in selecting and arranging learning experiences for learners to help them improve from 
the interpersonal to the intrapersonal stage (Verenikina, 2003). For example, when the learner pointing an object, the adult not only explain the object but also tell how the learner should behave towards the object (Engelbrecht, \& Tharp, 2010). According to Vygotsky's theory, the Proximal Development Zone is the gap between the actual development and the potential development, whether a child can do something without the help of an adult and whether a child can do something with adult direction or cooperation with peers (Jamalinesari, et al., 2015).

The purpose of ZPD is emphasizing ZPD on social interaction that can facilitate the development of children (Kuusisaari, 2014). When learners do their task in their schools, their development is likely to be slow. To maximize the progress, learners should work on the task with more-competent friends who can lead them systematically in solving more complex problems. Through successive changes in speech and attitude, learners discuss their new understanding with their friend then match, explore and use it (Van der Walt, et al., 2008). A consequence of this process is that learners learn selfregulation.

Responding to Piaget's view, which stated that there is a universal age as the standard age. The stages are: 0-2 years is the stage of development of sensory-motor stage, stage of motor sensory development, age 2 to 5 years is the preoperational stage, 7-11 years is the concrete operation stage, and 12 years or more is the stage of mind control. Vygotsky stated not to solely be tied to what is used by Piaget, especially Piaget conducted the research in the orphanage, which means that the research examines children whose growth is not normal since those children have no family except their friends. In fact, it is essential to interact with others (Shooshtari, et al., 2017).

Therefore, Vygotsky proposed a theory known as the Zone of Proximal Development (ZPD), which is an important socio-cultural dimension as a psychological dimension. ZPD is the gap between the actual development level and the level of potential development. The level of development consists of four stages (Wass, et al., 2014).

First, more dependence to others stage, the stage where children's performance gets much help from others such us, peers, parents, teachers, community, experts, and so on. The cooperative and collaborative learning model is occurred in developing a child's cognitive constructively. 
Second, less dependence external assistance stage, where children's performance does not need too much help from others, but it is more self-help, where the children help themselves.

Third, Internalization and automatization stage, where children's performance has been more internalized automatically. Awareness of the importance of self-development can arise by itself without being given any pressure and greater direction from others. However, the child at this stage has not reached the real maturity yet. Moreover, they are still seeking self-identity in an effort to achieve mature self-capacity.

Fourth, De-automatization stage, where children's performance is able to express feelings of the heart, soul, and emotions, which is done repeatedly, back and forth, recursion. At this stage, de-automatization as the culmination of real performance has occurred (Green, 2015).

In order to describe how the children development from the capacity stage begins to function until the period of further development, can be seen in Figure 2.

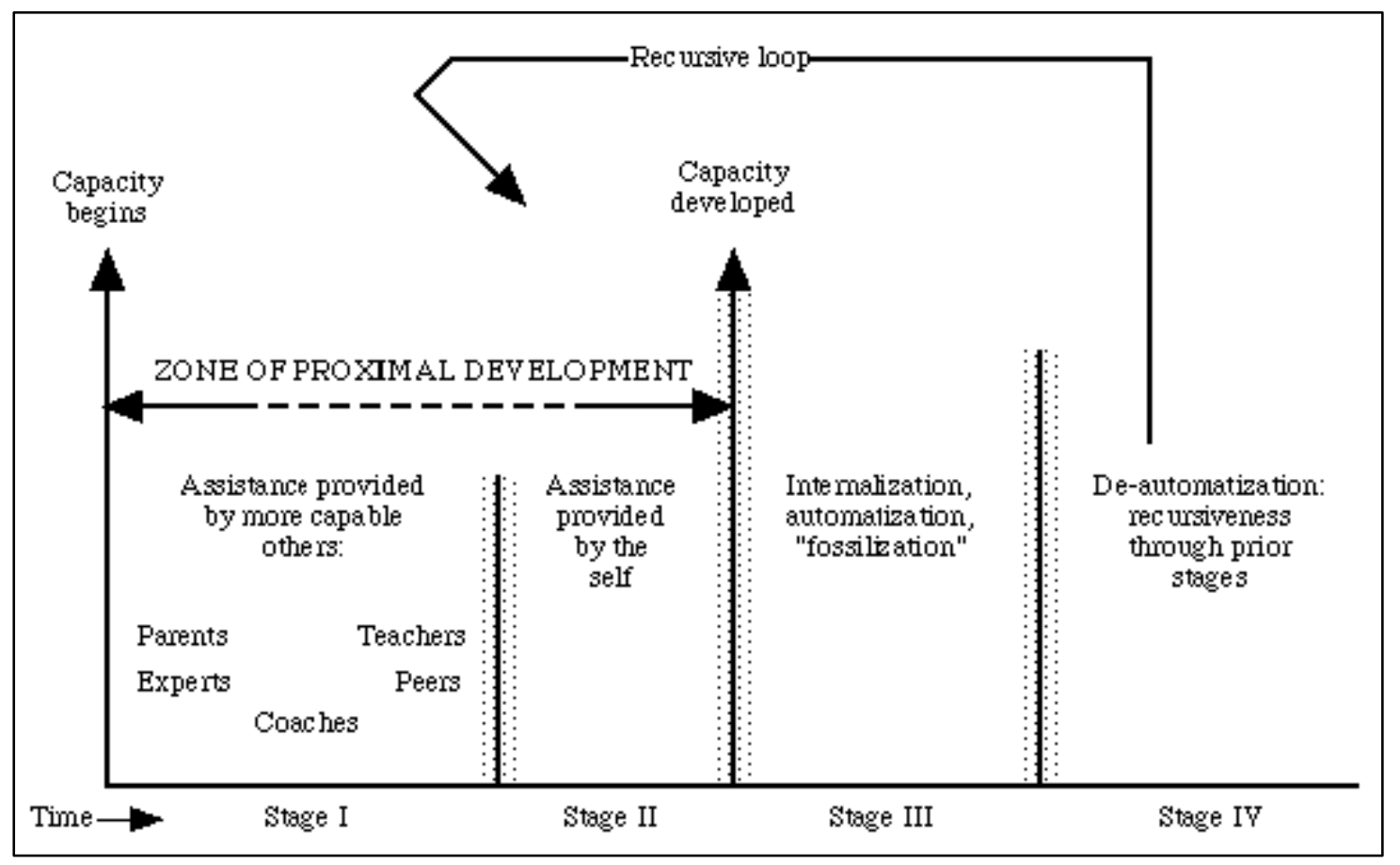

Figure 2. Model of four stages in the zone of proximal development (Gallimore \&Tharp, 1990)

Stage I: The first stage demonstrates how learners develop an understanding of language that is appropriate to their study and the basics of the topic under study by 
relying on others such as instructors to perform the task.

Stage II: In the second stage, learners use prior knowledge to carry out the task without any guidance. The ZPD occurs between the first and second stages. Learners practice alone, which implies that they perform certain activities without help. However, they are not at a stage of perfect proficiency and require some help sometimes.

Stage III: In the third stage performance is developed, is happening without thinking and knowledge is fixed and it cannot be forgotten. This means that at this stage learners reach the stage of independence. In this stage, a student does not need help from an adult, nor to practice more exercises to reinforce the already existing knowledge (Gallimore \& Tharp, 1990).

Stage IV: In the fourth stage learners are at the de-automatization of performance that leads to the process of repeating a function, each time applying it to the results of the previous stage through the ZPD. Lifelong learning by an individual is made up of the same regulated ZPD sequences, from other-help to self-help recurring over and over again for the development of new capacities (Gallimore \& Tharp, 1990)

Vygotsky is a scientist who emphasized the importance of paying attention to social construction. In his opinion, in human development and behavior, there is always a process of conformity between the behavior and social construction, the process of appropriation by behavior. (Fani, et al., 2011).

Appropriation means the appropriateness of behavior with the social constructions found in social lives (Mayer, 2014). Therefore, the theory is known as social constructivist. On the other hand, Piaget builds his theory on the personal development of individuals, which is put in the theory of personal constructivist by most scientists.

Piaget is closely related to the process of human biological basis. Meanwhile, Vygotsky stated that cognitive development is closely related to the process of human biological basis, which has many similarities to several kinds of animals, but there is still a high psychological such us every child born with a range of abilities, perceptions, and concerns in a social and educational context that will be transformed.

It means, the change occurs when the child is educated in a social context through certain social laws, languages, tools, cultures that can make the psychological function cognition much higher. This is the characteristic of Vygostsky view, which got great contradiction in Russia, especially from the behaviorists named Ivan Pavlov. 
Furthermore, Vygotsky also proposed the existence of scaffolder instruction, the learning that follows the leaps, which is divided into three major principles; the holistic meaning must be meaningful, must be in a particular social context, must have the opportunity to change and be related between one level with the next level (Yelland, et al., 2005).

If these three things can be put into reality, then it is called learning that uses reciprocal approach or known as the Reciprocal Teaching Approach. In fact, the child will have challenges associated with activities outside of his or her developmental level (Hanjani \& Li, 2014).

Statistical Method, Statistical Method is a learning skill that must be taken by all students of mathematics. Knowledge of Calculus and Basic Statistics is all the materials in mind needed. One of the materials in the Statistical Method course is the "Standard Deviation and Various Sizes of Dispersions", which is a Method for knowing the degree to which numeric data has a tendency to spread around its mean value known as dispersion/variation or variation of the data. There are various sizes of data variations, including those commonly used are data range, mean deviation, standard deviation and so on.

The mean deviation in the short MD (mean deviation) of a set of data/numbers $\mathrm{X}_{1}, \mathrm{X}_{2}, \cdots, \mathrm{X}_{\mathrm{n}}$ defined as,

$$
\mathrm{MD}=\frac{\sum_{\mathrm{i}=1}^{\mathrm{n}}\left|\mathrm{X}_{\mathrm{i}}-\overline{\mathrm{X}}\right|}{\mathrm{n}}=\frac{\left|\mathrm{X}_{1}-\overline{\mathrm{X}}\right|+\left|\mathrm{X}_{2}-\overline{\mathrm{X}}\right|+\cdots+\left|\mathrm{X}_{\mathrm{n}}-\overline{\mathrm{X}}\right|}{\mathrm{n}}
$$

where $\bar{X}$ is the arithmetic mean (average) and $\left|X_{i}-\bar{X}\right|$ is the absolute value of the deviation $X_{i}$ to $\bar{X}$. If $\mathrm{X}_{1}, \mathrm{X}_{2}, \cdots, \mathrm{X}_{\mathrm{n}}$ each has a frequency $f_{1}, f_{2}, \cdots f_{n}$, then the mean deviation formula is,

$$
\mathrm{MD}=\frac{\sum_{\mathrm{i}=1}^{\mathrm{n}} \mathrm{f}_{\mathrm{i}}\left|\mathrm{X}_{\mathrm{i}}-\overline{\mathrm{X}}\right|}{\mathrm{n}}
$$

where $X_{i}$ presenting class marks and $f_{i}$ state frequency and $n=\sum_{i=1}^{n} f_{i}$.

Sample standard deviation from the set of $\mathrm{n}$ data $\mathrm{X}_{1}, \mathrm{X}_{2}, \cdots, \mathrm{X}_{\mathrm{n}}$ defined as,

or

$$
\begin{aligned}
& \mathrm{s}=\sqrt{\frac{\sum_{\mathrm{i}=1}^{\mathrm{n}}\left(\mathrm{X}_{\mathrm{i}}-\overline{\mathrm{X}}\right)^{2}}{n}}=\sqrt{\frac{\left(\mathrm{X}_{1}-\overline{\mathrm{X}}\right)^{2}+\left(\mathrm{X}_{2}-\overline{\mathrm{X}}\right)^{2}+\cdots+\left(\mathrm{X}_{\mathrm{n}}-\overline{\mathrm{X}}\right)^{2}}{\mathrm{n}}} \\
& \mathrm{S}=\sqrt{\frac{\sum \mathrm{X}_{\mathrm{i}}^{2}}{\mathrm{n}}-\left(\frac{\sum \mathrm{X}_{\mathrm{i}}}{\mathrm{n}}\right)^{2}}
\end{aligned}
$$


Formula (3b) more carefully, because there is less rounding than the formula (3a). If $\mathrm{d}_{\mathrm{i}}=\mathrm{X}_{\mathrm{i}}-\mathrm{A}$ is a deviation $X_{i}$ against an arbitrary constant $\mathrm{A}$, formula $(3 \mathrm{~b})$ will be:

$$
\mathrm{s}=\sqrt{\frac{\sum \mathrm{d}_{\mathrm{i}}^{2}}{\mathrm{n}}-\left(\frac{\sum \mathrm{d}_{\mathrm{i}}}{\mathrm{n}}\right)^{2}}
$$

In understanding Standard Deviation and Various Sizes of Dispersions correctly, Vygotsky's provides steps that are followed by students, namely work is based on three main ideas: (1) Intellectual develops as new ideas and finds it difficult to associate them with what they already know; (2) Interaction with others enriches intellectual development; (3) the teacher's primary role is as an assistant and mediator in student learning (Padayachee, et al., 2011).

\section{RESEARCH METHOD}

The data used are data taken from the statistical method class as many as 50 students who obtained treatment of ZPD and 42 students without ZPD, in the final semester of 2018/2019 in the Hasanuddin University Statistics Departement. Retrieval of data with Purposive sampling method. Retrieval of data with Proporsive sampling method, where the researcher determines the sampling by determining specific characteristics that fit the research objectives so that it is expected to answer the research problem. Stages of data analysis is follow:

1. Determine learning classes with different treatments, namely by giving ZPD and without ZPD.

2. Provide the same test for the two learning classes

3. Apply ZPD to learning classes that get the treatment of giving ZPD.

4. Integrating learning to enable social transmission, namely the interaction and cooperation of a person with others or with the environment, such as interaction and cooperation between students, teachers, and students.

5. Utilizing a variety of media, including oral and written communication for more effective learning.

6. Involving students emotionally and socially so students become interested and want to learn.

7. Giving Posttest for both learning classes, with the same questions at the pretest.

8. Evaluate the results of both learning classes. 


\section{RESULTS AND DISCUSSION}

Questions given by students in the learning class by implementing ZPD and without ZPD : Calculate the standard deviation of the data : $12 ; 6 ; 7 ; 3 ; 10 ; 15 ; 5 ; 18$ $; 8 ; 4$.

Solution: Create the following help table:

\begin{tabular}{|c|c|c|}
\hline $\mathrm{X}_{\mathrm{i}}$ & $\begin{array}{c}\text { Deviation } \\
\mathrm{X}_{\mathrm{i}}-\overline{\mathrm{X}}\end{array}$ & $\begin{array}{c}\text { Squared deviation } \\
\left(\mathrm{X}_{\mathrm{i}}-\overline{\mathrm{X}}\right)^{2}\end{array}$ \\
\hline 12 & 3.2 & 10.24 \\
6 & -2.8 & 7.84 \\
7 & -1.8 & 3.24 \\
3 & -5.8 & 33.64 \\
10 & 1.2 & 1.44 \\
15 & 6.2 & 38.44 \\
5 & -3.8 & 14.44 \\
18 & 9.2 & 84.64 \\
8 & -0.8 & 0.64 \\
4 & -4.8 & 23.04 \\
\hline$\sum=88$ & $\sum=\mathbf{0}$ & $\sum\left(\mathrm{X}_{\mathrm{i}}-\overline{\mathrm{X}}\right)^{2}=217.6$ \\
$\bar{X}=8.8$ & & $\sum$ \\
\hline
\end{tabular}

\begin{tabular}{|c|c|}
\hline $\mathrm{X}_{\mathrm{i}}$ & $\mathrm{X}_{\mathrm{i}}^{2}$ \\
\hline 12 & 144 \\
6 & 36 \\
7 & 49 \\
3 & 9 \\
10 & 100 \\
15 & 225 \\
5 & 25 \\
18 & 324 \\
8 & 64 \\
4 & 16 \\
\hline$\sum=88$ & $\sum \mathrm{X}_{\mathrm{i}}^{2}=992$ \\
\hline
\end{tabular}

So the standard deviation (formula 3a) is:

$$
\begin{aligned}
\mathrm{S} & =\sqrt{\frac{\sum_{\mathrm{i}=1}^{\mathrm{n}}\left(\mathrm{X}_{\mathrm{i}}-\overline{\mathrm{X}}\right)^{2}}{n}} \\
& =\sqrt{\frac{217.6}{10}} \\
& =4.6648
\end{aligned}
$$

By formula (3b):

$$
\begin{aligned}
s & =\sqrt{\frac{\sum X_{i}^{2}}{n}-\left(\frac{\sum X_{i}}{n}\right)^{2}} \\
& =\sqrt{\frac{992}{10}-\left(\frac{88}{10}\right)^{2}} \\
& =\sqrt{99.2-77.4} \\
& =\sqrt{21.76} \\
& =4.6648
\end{aligned}
$$


Through the continued changes in speaking and behaving, students discussed their understanding of Standard Deviation and Various Sizes of Dispersions correctly with their friends, then comparing and deep learning, then using it. A consequence of this process is that the students learned self-regulation. After implementing the steps of ZDP, it is seen that student with limited capabilities is also able to understand the concept of Standard Deviation and Various Sizes of Dispersions correctly as well as students with good capability.

Based on the results of observations and interviews with students who contracted Mathematics Statistics Courses at one of the State universities in Makassar City related to the ability of ZPD, it was seen that some students still had difficulty understanding the writing flow of the concepts used. One of the factors that resulted in this was the weak concept of prerequisite courses (Calculus and Basic Statistics).

For the Calculus Course, some students admitted that they were still weak in mastering the concept of partial derivatives, especially in solving questions related to more complex partial derivatives. They are sometimes confused when lowering a variable partially if there are many variables in the function. They are still weak in applying derivative techniques in solving derivative questions, such as the derivative concept of multiplication and division of two or more functions, and the concept of chain rules in derivatives.

For Basic Statistics Courses, some students admitted that they were still weak in the concept of expectations, especially regarding moments. They are often confused between concepts by definition and proposition; and there is still a lack of understanding of students regarding the relationship between the concepts of expectations, mean, variance, and covarians.

To strengthen the analysis, researchers also observed and interviewed one of the lecturers in the Mathematics Statistics Course. The lecturer acknowledges that the learning model used is still conventional which emphasizes the activities of lecturers in explaining the material, question and answer, and deepening the material through work and discussion of practice questions. The lecturer also admitted that the mastery of several students on prerequisite courses was still weak, so often the lecturer had to review the material. By reviewing the prerequisite material, students can better understand the Mathematical Statistics material which often requires reading skills to 
understand better concepts. With Scaffolding help, it is seen that ZPD students are developing very rapidly based on the final test given. Overall, the average post-test scores of students who went through the ZPD process were 24.62, while students who did not go through the ZPD process were only 19.3.

Table 1. Descriptive Statistics Data of student ZPD ability

\begin{tabular}{|c|c|c|c|c|c|c|c|c|c|c|c|c|c|}
\hline \multirow{2}{*}{$\begin{array}{l}\text { Initi } \\
\text { al } \\
\text { Abil } \\
\text { ity } \\
\text { Test }\end{array}$} & \multirow[b]{2}{*}{$\begin{array}{l}\text { St } \\
\text { at }\end{array}$} & \multicolumn{4}{|c|}{ With ZDP } & \multicolumn{4}{|c|}{ Without ZDP } & \multirow[b]{2}{*}{$\begin{array}{l}\text { Pre } \\
\text { test }\end{array}$} & \multicolumn{3}{|c|}{ Total } \\
\hline & & $\begin{array}{l}\text { Pre } \\
\text { test }\end{array}$ & $\begin{array}{l}\text { Pos } \\
\text { test }\end{array}$ & $<\mathbf{g}>$ & $\mathbf{N}$ & $\begin{array}{l}\text { Pre } \\
\text { test }\end{array}$ & $\begin{array}{l}\text { Pos } \\
\text { test }\end{array}$ & $\begin{array}{c}<\mathbf{g} \\
>\end{array}$ & $\mathbf{N}$ & & $\begin{array}{l}\text { Pos } \\
\text { test }\end{array}$ & $\begin{array}{c}<\mathbf{g} \\
>\end{array}$ & $\mathbf{N}$ \\
\hline 1 & 2 & 3 & 4 & 5 & 6 & 7 & 8 & 9 & $\begin{array}{l}1 \\
0\end{array}$ & 11 & 12 & 13 & 14 \\
\hline \multirow{2}{*}{$\begin{array}{c}\text { Hig } \\
\text { h }\end{array}$} & $\bar{x}$ & $\begin{array}{c}22,7 \\
5\end{array}$ & $\begin{array}{c}37,7 \\
7\end{array}$ & 0,87 & \multirow[t]{2}{*}{4} & $\begin{array}{c}24,2 \\
5\end{array}$ & $\begin{array}{c}26,3 \\
3\end{array}$ & $\begin{array}{c}0,5 \\
6\end{array}$ & \multirow{2}{*}{3} & $\begin{array}{c}23,5 \\
0\end{array}$ & $\begin{array}{c}32,0 \\
5\end{array}$ & $\begin{array}{c}0,7 \\
2\end{array}$ & \multirow{2}{*}{7} \\
\hline & $\mathrm{S}$ & 3,50 & 4,66 & & & 0,89 & 1,53 & & & & & & \\
\hline \multirow{2}{*}{$\begin{array}{c}\text { mid } \\
\text { dle }\end{array}$} & $\bar{x}$ & $\begin{array}{c}13,8 \\
4 \\
\end{array}$ & $\begin{array}{c}25,2 \\
4 \\
\end{array}$ & 0,44 & \multirow[t]{2}{*}{$\begin{array}{l}3 \\
2\end{array}$} & $\begin{array}{c}12,3 \\
7 \\
\end{array}$ & $\begin{array}{c}18,8 \\
5 \\
\end{array}$ & $\begin{array}{c}0,4 \\
1 \\
\end{array}$ & \multirow{2}{*}{$\begin{array}{l}3 \\
3\end{array}$} & $\begin{array}{c}13,1 \\
1 \\
\end{array}$ & $\begin{array}{c}22,0 \\
5 \\
\end{array}$ & $\begin{array}{c}0,4 \\
3 \\
\end{array}$ & \multirow{2}{*}{65} \\
\hline & $\mathrm{S}$ & 2,70 & 3,13 & & & 4,99 & 2,43 & & & & & & \\
\hline \multirow[t]{2}{*}{ Low } & $x$ & 5,29 & 7,50 & 0,47 & \multirow[t]{2}{*}{$\begin{array}{l}1 \\
4\end{array}$} & 1,25 & 9,17 & $\begin{array}{c}0,3 \\
0 \\
\end{array}$ & \multirow{2}{*}{6} & 3,27 & 8,33 & $\begin{array}{c}0,3 \\
9\end{array}$ & \multirow{2}{*}{20} \\
\hline & $\mathrm{S}$ & 2,27 & 1,91 & & & 1,50 & 1,33 & & & & & & \\
\hline \multirow{3}{*}{$\begin{array}{c}\text { Sub } \\
\text { Tota } \\
\text { l } \\
\end{array}$} & $\bar{x}$ & 14,1 & 24,6 & 0 & \multirow{3}{*}{$\begin{array}{l}5 \\
0\end{array}$} & 13,2 & 19,3 & 0,4 & \multirow{3}{*}{4} & 13,6 & 21,5 & 0,3 & \multirow{3}{*}{92} \\
\hline & & 6 & 2 & U & & 1 & 3 & 0 & & 9 & 1 & 7 & \\
\hline & $\mathrm{S}$ & 5,69 & 7,80 & & & 9,40 & 5,62 & & & & & & \\
\hline
\end{tabular}

Description: Ideal maximum score 45.

Table 1. shows that based on descriptive statistics for ZPD capability data in general are as follows:

1. The average achievement and improvement of ZPD capabilities overall students who received Scaffolding assistance were greater than students who did not receive Scafolding assistance. The overall ZPD ability of students with high Initial Ability Test who received scaffolding assistance was greater than students who did not receive Scaffolding assistance.

2. The average achievement and improvement of ZPD capabilities as a whole students Initial Initial Ability Test who receive scaffolding assistance is greater than students who do not receive Scaffolding assistance. 
3. The average achievement and improvement of overall mathematical problem solving abilities of students with low initial ability tests who received scaffolding assistance were greater than students who did not receive Scaffolding assistance.

\section{CONCLUSION}

Using scaffolding help, it is seen that ZDP students are developing very rapidly based on the final test given. Overall, the average post-test scores of students who went through the ZDP process were 24.62, while students who did not go through the ZPD process were only 19.3. Students' ZPD development is occurred, by implementing the Scaffolding gradual knowledge in thorough several help for students in the first stages of learning, then reduce and give students the chance to take responsibility based on their ability. The help in the form of guidance, warning, encouragement, outlining problems at solving steps, and giving examples especially in understanding the basic concepts

\section{REFERENCES}

Angeli, Ch., \& Valanides, N. (2004). The effect of electronic scaffolding for technology integration on perceived task effort and confidence of primary student teachers. Journal of Research on Technology in Education, 37(1), 29-43.

Anthony, G., \& Walshaw, M. (2009). Characteristics of effective teaching of mathematics: A view from the west. Journal of Mathematics Education, 2(2), 147164.

Atebe, H.U. (2011). The van Hiele levels as correlate of students' ability to formulate conjectures in school geometry. In H. Venkat \& A.A. Essien (eds). Proceedings of the 17th National Congress of the Association for Mathematics Education of South Africa (AMESA): Mathematics in a Globalised World, 1: 11-15.

Borchelt, N. (2007). Cognitive computer tools in the teaching and learning of undergraduate calculus. International Journal for the Scholarship of Teaching and Learning, 1(2), 1-17.

Camiciottoli, B.C., \& Fortanet-Gómez, I., (2015). Multimodal analysis in academic settings. London: Routledge.

Engelbrecht, J., Harding, A., \& Phiri, P. (2010). Are OBE-trained learners ready for 
university mathematics? Pythagoras, 7(2), 3-13.

Gallimore, R., \& Tharp, R. (1990). Teaching mind in society: Teaching, schooling, and literate discourse. in Moll, L.C. (ed). Vygotsky and Education: Instructional implications and applications of sociohistorical psychology. Cambridge: Cambridge University Press.

Green, J.H. (2015). Teaching for transfer in EAP: Hugging and bridging revisited. English for Specific Purposes, 37(1), 1-12.

Hanjani, A.M., \& Li, L. (2014). Exploring L2 writers' collaborative revision interactions and their writing performance. System, 44, 101-114.

Jamalinesari, A., Rahimi, F., Gowhary, H., \& Azizifar, A. (2015). The effects of teacherwritten direct vs. indirect feedback on students' writing. Procedia - Social and Behavioral Sciences, 192, 116-123.

Kuusisaari, H. (2014). Teachers at the zone of proximal development: Collaboration promoting or hindering the development process. Teaching and Teacher Education, 43, 46-57.

Mayer, R.E. (2014). Cognitive theory of multimedia learning. In R.E. Mayer (ed.), The Cambridge handbook of multimedia learning, 31-48. New York: Cambridge University Press.

Ndlovu, M.C. (2011). University-school partnerships for social justice in mathematics and science education: the case of the SMILES project at IMSTUS. South African Journal of Education, 31(3), 419-433.

Padayachee, P., Boshoff, M., Olivier, W., \& Harding, A. (2011). A blended learning Grade 12 intervention using DVD technology to enhance the teaching and learning of mathematics. Pythagoras, 32(1), 1-8.

Shooshtari, Z.G., Jalilifar, A., \& Haghighi, S.B. (2017). A multimodal approach toward teaching for transfer: A case of team teaching in EASP writing courses. Journal of Teaching Language Skills, 35(4), 157-190.

Tayebeh, F., \& Ghaemi, F. (201). Implications of Vygotsky's Zone of Proximal Development in Teacher Education: ZPTD and Self-scaffolding. Procedia - Social and Behavioral Sciences, 29. 1549-1554.

Van der Walt, M., Maree, K., \& Ellis, S. (2008). A mathematics vocabulary questionnaire for use in the intermediate phase. South African Journal of 
Education, 28(4), 489-504.

Verenikina, I. (2003). Understanding scaffolding and the ZPD in educational research. Proceedings of the International Education Research Conference (AARE NZARE). Wollongong: University of Wollongong, Australia.

Wass, R., \& Golding, C. (2014). Sharpening a tool for teaching: the zone of proximal development. Teaching in Higher Education, 19(6), 671-684.

Yelland, N., \& Masters, J. (2007). Rethinking scaffolding in the information age. Computers \& Education, 48(3), 362-382. 